Abbreviated Key Title: Sch J Econ Bus Manag

ISSN 2348-8875 (Print) | ISSN 2348-5302 (Online)

Journal homepage: https://saspublishers.com/sjebm/

\title{
Socio-Economic Empowerment of Rural Women through Self-Help Groups: A Study \\ S. Chittemma ${ }^{1}, \mathrm{~K}_{\text {Dasaratharamaiah }}{ }^{2 *}$
}

\author{
${ }^{1}$ Ph.D. Scholar, Department of Economics, Sri Krishnadevaraya University, Ananthapuramu, A.P. and Lecturer in Economics, STSN Govt. Degree \\ College, Kadiri, Ananthapuramu District, A.P, India \\ ${ }^{2}$ Professor, Department of Economics and Applied Economics, Sri Krishnadevaraya University, Ananthapuramu, A.P, India
}

DOI: $10.36347 /$ sjebm.2020.v07i05.004

| Received: 14.05.2020 | Accepted: 21.05.2020 | Published: 30.05.2020

*Corresponding author: Konanki Dasaratharamaiah

Abstract

Original Research Article

The empowerment is the process of obtaining basic opportunities for marginalized people, either directly or indirectly by the government, NGOs and non-marginalized people in the society. In recent years, the rural women are gaining empowerment with the support of various developmental programs initiated for the women development from time to time. One of the important program for women development and empowerment is the Self-Help Groups (SHGs) in the country as a whole. With the help of SHGs, the rural women are gaining income and employment opportunities. With the income generation and asset creation through Self-Help Groups, they are empowered socially, economically, educationally, politically and psychologically in the society. The SHGs in several parts of the country have achieved success in bringing the women to the major stream of decision making. The SHGs in our country have become a source of inspiration for women's welfare and formation of SHGs is a viable alternative to achieve the objectives of rural development and to get community participation in all rural development programs which in turn is providing women empowerment in all aspects. The present study is focused on empowerment of women through SHGs with a basis of before and after the SHG programs in the study area.

Keywords: Women Empowerment, Self-Help Groups, Decision Making, Awareness, Rural Women, Savings, Spending Money, Gram Sabhas, Political Participation, Income Generation, Expenditure.

Copyright @ 2020: This is an open-access article distributed under the terms of the Creative Commons Attribution license which permits unrestricted use, distribution, and reproduction in any medium for non-commercial use (NonCommercial, or CC-BY-NC) provided the original author and source are credited.

\section{INTRODUCTION}

The Empowerment is a set of measures designed to enhance the autonomy and selfdetermination among the individual as well as communities enable them to focus their interests in a self-confidential manner by acting their own determination. The empowerment is the process of obtaining basic opportunities for marginalized people, either directly by those people, or through the help of non-marginalized others who share their own access to these opportunities. The empowerment includes actively thwarting attempts to deny those opportunities. It also includes encouraging and developing the skills for self-sufficiency with a focus on eliminating the future need for the welfare in the individuals or of the group of communities. Empowerment is one of the main procedural concerns when addressing human rights and development. In simple terms, empowerment means giving power or authority to an individual.

\section{Gender Empowerment}

The gender empowerment is the empowerment of people of any gender. While conventionally, the aspect of it is mentioned for empowerment of women, the concept stresses the distinction between biological sex and gender as a role, also referring to other marginalized genders in a particular political or social context. In the present days, the gender empowerment has become an important one for discussion in the concept of development and economics. Entire Nations, communities and groups can benefit from the implementation of various programs and policies that adopt the notion of women empowerment. The Human Development and Capabilities Approach, The Millennium Development Goals, and other credible approaches or goals point to empowerment and participation as a necessary step, if a country is to overcome the obstacles associated with poverty and development. Gender empowerment can be measured through the Gender Empowerment Measure, or the GEM. The GEM shows women's participation in a given nation, both politically and economically. GEM is calculated by tracking the share of seats in parliament 
held by women, of female legislators, senior officials and managers and of female profession and technical workers, and the gender disparity in earned income, reflecting economic independence. Then, it ranks the countries given this information. Other measures that take into account the importance of female participation and equality includes the Gender Parity Index (GPI) and the Gender Development Index (GDI).

\section{Empowerment of Women}

The Empowerment of women is gaining ground and an added significance in the Indian context owing to their profusive participation in developmental activities. Gandhiji stated that women are companion of men gifted with equal mental capacities. She has a right to participate in the minute details of the activities of man and she has the same right to freedom and liberation of man. Women Empowerment has become a subject of growing importance around the world in contemporary times. The concern is seen at different levels and circles which includes governments, bureaucracy, NGOs, academicians and other researchers who have been concentrated on the empowerment of women in various aspects from time to time. As India strives towards equal rights, a change in the perceptions of men and women is needed to reduce gender disparity.

The empowerment of women has been extensively debated and written about all over the world. Sociologist Dhruba Hazarika has rightly said that empowerment of women means equipping them to be economically independent, self-reliant in addition to providing positive self-esteem to face any difficult situation. Women should be equipped enough to participate in any development process. Women in Indian society have come a long way from the days of being worshipped as goddesses to being molested and harassed-gruesome domestic violence cases, acid attacks and rapes. Over the years, a steady rise in the adversities faced by Indian women and girls has taken place. The Indian constitution grants certain constitutional and legal privileges to women pertaining to equality and fundamental rights, some special provisions were also introduced to strengthen the process of providing equal status to women. The empowerment doesn't have a straightforward definition because it means something different to everyone. Keshab Chandra Mandal wrote that female empowerment could be defined in five categories such as social, educational, economic, political and psychological empowerment.

\section{Social Empowerment of Women}

The social empowerment might be one of the most prominent forms of empowerment shown in the mainstream media. It strengthens women's social relations and their positions in social structures, giving them more of a purpose outside of the home. Their contributions to society are recognized and valued as opposed to look down upon simply because it was a woman's creation. Social empowerment also fights back against discrimination, no longer letting people of different disabilities, races, ethnicities, religions, or genders be walked over by what's considered, normal.

\section{Educational Empowerment of Women}

Education is a crucial part of growing and developing, but there are still places in the world that deny education to girls. This takes away a fundamental skill everyone has the right to knowledge. Without a proper education for all, gender empowerment isn't possible. Education puts everyone on equal footing and lets young girls have access to what their rights and duties are. Not only that, obtaining knowledge can boost self-confidence, self-esteem and make girls selfsufficient. It also gives them access to the development of social, political, intellectual and religious consciousness and can discourage the growth of bigotry, narrow-mindedness, superstition, intolerance and so on.

\section{Economic Empowerment of Women}

People say money can't buy happiness, but being at an economic disadvantage can take away access to becoming empowered. Being poor, landless, deprived, or oppressed doesn't allow access to resources that those in good financial standings do. Closing this gap would allow everyone to have equal footing and women in particular would gain a more significant share of control over the material, human, intellectual and financial resources.

\section{Political Empowerment of Women}

Having a voice in politics can be substantial in letting a group's view be pushed into the light of mainstream media and that's no different for advocating women's rights. The political involvement of women, implies the decentralization of power and authority in the deprived, oppressed, and powerless people who have not been able to participate in the decision-making process and the implementation of policies and programs of both government and organizations as well as familial and societal matters. In other words, having political influence would not only give a voice to those who haven't had a voice in how things are governed, but it would also allow the possibility of policies and programs being put into place that would work with these discriminated groups.

\section{Psychological Empowerment of Women}

Psychological empowerment aligns with social empowerment. It transgresses the "traditional and patriarchal taboos and social obligations" and lets women go beyond what's expected of them in society. This can build self-confidence, help women to recognize their self-worth and gives them the chance to take control of their income and body. All five of these categories intertwine with one another, but it's equally important to consider them separately as well. Each 
group has different main goals they're aiming for, so trying to focus on them as a whole would be unbeneficial ultimately. Knowing what work has to be put into these five categories of employment can provide a boost in the right direction and allow empowerment not just for women, but eventually for all. The SHGs are playing a crucial role in achieving all the above categories of empowerment by the rural women in India.

\section{Self-Help Groups (SHGs) and Women Empowerment in India \\ The year 2001 had been declared by the} Government of India, as 'Women Empowerment Year' to focus on a vision where women are equal partners like men. Because, the Constitution of India Grants equality to women in different fields of life. In the past, the situation of women was miserable in the society and even women were not ready to undertake any task due to many reasons like fear, shyness, male dominance in the society and purda system among the women in some communities, but time has been changed now. Women of today are not like the early days. Now, they are willing to come forward and want more socioeconomic independence as they expecting their own identity, achievements, equal status in the society and greater freedom.

In this situation, the Government of India has provided Self Help Groups (SHGs) to them so that proper attention should be given to their economic independence through self-employment, entrepreneurial development and well-being that finally leads to its contribution. SHGs have been emerged as a powerful instrument in order to alleviate poverty and gaining empowerment of women in the rural India. SHGs through the network of Commercial Banks, Cooperative Banks, Regional Rural Banks, NABARD and NGO's has been largely supply driven and a recent approach in the provision of financial services to the poor and further upgrading their status in the society. In this way, SHGs are playing a significant role to reduce rural poverty and to promote rural savings along with provision of gainful employment opportunities among the rural women community.

The Women Self Help Groups in several parts of the country have achieved success in bringing the women to the major stream of decision making. The SHGs in our country have become a source of inspiration for women's welfare and formation of SHGs is a viable alternative to achieve the objectives of rural development and to get community participation in all rural development programs. SHG is also a viable organized set up to disburse micro credit to the poor women and hopeful them together into entrepreneurial activities. To alleviate the poverty and to empower the women, the micro-finance, Self-Help Groups (SHGs) and credit management groups have also on track in India. Self Help Group (SHG) is a small voluntary association to form a group. It is informal and homogenous group of not more than twenty members.

SHGs consist of maximum 20 members, because, any group having more than 20 members has to be registered under Indian legal system. That is why it is suggested to be informal to keep them away from bureaucracy, corruption, unnecessary administrative expenses and profit motive. In fact, it is a home grown model to eradicate poverty which simultaneously works to empower and shape the lives of its members in a better way. Groups are expected to be homogenous so that the members do not have conflicting interest and all the members can participate freely without any fear. Self-Help Groups (SHGs) movement has triggered off a soundless revolution in the rural credit delivery system in India. SHGs have proved as an effective medium for delivering credit to rural poor especially for rural women for their socio-economic empowerment.

The empowerment by way of involvement in SHG can bring changes and enhancement in the living conditions of women. The underlying principle of SHGs is to afford to the poorest of the poor and to achieve empowerment. The SHG is a procedure by which a large group of women i.e. 10-20, with common objectives are facilitated to come together voluntarily to participate in the development activities such as saving, credit and income generation thereby ensuring economic independence among them. The SHG phenomenon definitely brings group awareness among women, sense of belongingness, adequate selfconfidence. In fact, what she cannot achieve as an individual, can accomplish as a member of group with sufficient understanding about her own rights, roles, civil liberties and responsibilities as a dignified member of society on par with men. When she becomes a member of SHG, her sense of public participation, enlarged horizon of social activities, high self-esteem, self-respect and fulfillment in life expands and enhances the quality of status of women as participants, decision makers and beneficiaries in the democratic, economic, social and cultural spheres of life.

The experiences of SHGs in various countries have been achieving great success as an effective plan and approach in recent years. Group-oriented efforts in the form of Micro-credit groups in different countries of Latin America, Africa and Asia are examples of current self-help efforts. The Grameen Groups in Bangladesh, Local Self-Help development efforts-harambee in Kenya, Tontines or Hui with 10 to 15 members involved in financial activities through cash or kind in Vietnam, Self-Help efforts through credit unions, fishermen groups, village-based banks, irrigation groups etc., in Indonesia, the SHGs in countries like Thailand, Nepal, Sri Lanka and India are successfully proving forms of micro-credit groups or SHGs. 
As a group-oriented model, SHG in India is a mechanism for women development to bring in individual and collective empowerment. Now, women in India are mobilized to protest against domestic violence, rising prices, legal inequity, rape, child marriage, domestic violence etc. In this way, it aims to empower women with various forms of power. Several factors and strategies have been provided by the SHGs that have made a positive contribution to the empowerment of women. These are full support and timely advice for balancing family and business responsibilities, leadership, experience in decision making and discussions on social issues. Women who joined in these groups enable themselves to face their household poverty through self-employment started at the initiative of SHGs. So, it is necessary to assess their role in empowering the women in rural India.

\section{REVIEW OF LITERATURE}

The available studies, reports and records have been reviewed in the following pages. According to Mohanan [1], the Self-Help scheme to help poorest of the poor must at the heart of the new strategy to combat poverty. Puhazhendhi [2], observed the functioning of SHGs, relating to its performance, sustainability, empowerment of women, economic impact on the members, future potentials etc. The emerging trends are leading to positive direction of empowerment of members and promotion of micro finance.

Gurumurthy [3], observed that SHG is a viable alternative to achieve the objectives of rural development and to get community participation in all rural development programs. SHG is a viable organizational setup to disburse micro credit to the rural women for the reason of making them entrepreneur and encouraging them to enter into entrepreneurial tricks. Vijayanthi [4], attempts to explain the procedure of women empowerment and find out the levels of awareness creation, decision making, empowerment among women from SHGs formed under Comprehensive Community Development Programme implemented in five slum areas of Chennai.

Bhatia and Bhatia [5], through little case studies highlighted that recovery of SHGs is higher than other credit extended to borrowers. Moreover, involvement of SHGs had helped the bank branches in recovery of old dues. They observed that there have been appreciable changes in the living standards of the SHG members in terms of ownership of assets, increase in savings and borrowing capacity, income generating activities and income levels as well. Mishra et al., [6], studied the impact of SHGs on income and employment generation among the beneficiaries identified the main constraints and problems faced by the groups and suggested measures for overcoming these problems in Faizabad district of eastern Uttar Pradesh.
According to Veluraj [7], the Nobel Scholar and Indian Economist Amartya Sen spoken in his words that, unless women have empowerment, issues like literacy, health and population explosion will remain unresolved problems of the developing countries. In India, the mainstream of the women still continue to perform their traditional roles in the household and in agriculture. Seibel and Kumar [8], revealed that SHGs in Karnataka paved the way for empowerment of women who are increasingly involved in community development programs and local politics. SHGs have potential to prevent social evils such as child marriage, child labour, and dowry and prevent harassment of women. K. Jothy [9], examined SHGs under the women development program. On the basis of indicators relating to districts covered, growth of SHGs and members, percentage of SC/ST members, growth of savings and growth of internal lending and internal rotation. The study ended with policy measures to overcome shortcomings.

V. M. Rao [10], maintain that a review of the genesis and development of SHGs in India reveals that the existing formal financial institutions have failed to afford finances to landless, marginalized and disadvantaged groups. The origin of SHGs could be treated to mutual aid in Indian village community. SHGs encourage savings and promote income generating activities through small loans. Bharat Dogra [11], presented in his article, Women Self Help Groups, that almost all these women are from poor families, mostly from dalits and backward classes, while the increase in income is important. It is not the only part of these SHGs which is emphasized.

Krishnaiah [12], studied Self Help Groups in Andhra Pradesh and observed that as a result of group formation, women were able to diversify their activities by undertaking non-farm and animal husbandry related activities. He fulfilled that repayment of loans by the groups is very high because of peer pressure, members are known to each other and they are aware of the credit worthiness of members and the good performance of repayment from members to groups and groups to banks helped to get higher loans subsequently. Sivaramakrishnan [12], has disclosed in his article, Poverty Alleviation through Self Help Groups, that the poverty levels have reduced from 56.44 per cent of India's population in 1973-74 to 37.27 per cent in 199394. The IX Five Year Plan document envisages reducing rural poverty in the country from a level of 30.55 per cent during 1996 to 9.64 per cent by 2006 and further to 4.31 per cent by 2011 .

Leelavathy [13], has expressed in her paper, 'SHG is a creamy layer for Women's social status' that the SHGs remove the curse of money lenders. SHGs are the ladder for upliftment of the down-trodden economically and socially. She has also pointed out that the SHGs are taking up construction work for their 
hamlets like laying of roads, closing down of liquor shops, contributing to the rehabilitation works and management of their village affairs. Kour [14], suggested that the state agencies should formulate SHGs and finance them on strict criteria for income generation and poverty alleviation and overall development. Sivachithappa [15], pin-pointed that SHG- based micro-finance and bank linkage program has better outreach and positive impact on poverty.

Latha Krishnan [16], analyzed the formation and functioning of SHGs and the impact on the socioeconomic status of underprivileged women. A pretested structured schedule was administered to collect the primary data from 350 SHG members and 30 animators. The study revealed that women come together as SHGs as they were able to get hassle-free and timely loans to meet emergence needs with thrift. Team spirit was acting as a binding factor to bring unity and cohesiveness among the group members. The SHG approach, apart from generating incremental income, helped them to upgrade the economic and social status along with a sense of recognition contributing to the process of empowerment.

Munian A [17], observed that the SHG Bank linkage approach is found to be an effective instrument by which very poor people can access hassle free formal credit without any collateral security and simultaneously improve their thrift habits. The approach also contributes to a social empowerment of the women. Pandey and Rini Roberts [18], examined the impact of participation in SHGs on the empowerment of women in Chamarajnagar district of Karnataka using personal narrative method. The authors recommended that it is necessary to provide a convergence of inputs, ensuring a proactive involvement of women in the program, changing social norms and perceptions and anchoring with wider movements of social change. Sahu Lopamudra and Singh [19], made a community based qualitative study in Pondicherry. It is found that the women SHG members have gained respect and trust in society and were able to plan for the future of their families. Authors observed that SHGs played a very important role in Women empowerment and should be promoted for economic development of the country.

Vijayalakshmi, Gowda, Jamuna, Ray, \& Sajjan [20], found that SHGs are improving the standard of living of poor families. Appropriate strategies for empowerment of SHG women were addressed through organizing appropriate trainings both on and offcampus, including higher level trainings, follow-up activities, providing relevant leaflets and folders, exposures besides recognizing and encouraging women to come forward and take up processing and of linger millet products value addition and income generating activities. Dhanalakshmi and Rajini [21], looks at the literature around the SHG movement in India. It examined the historical background of Self Help Groups in Indian context. It reviews the literature on the subject of empowerment process in relation to a Self Help Group as well as related literature.

Ramakrishna et al., [22], observed that SHGs are formed for addressing their common problems. They make regular savings habit and use the pooled savings for the benefit of their members through a structured process of essential financial intermediation like prioritization of needs, setting self-determined terms for repayment and keeping records. Kappa Kondal [23], conducted a study on women empowerment through Self-Help Groups in Gajwel Mandal of Medak district in Telangana. The major findings of the study reveals that there is a positive impact of Self Help Groups on Women empowerment in Gajwel Mandal of Medak district. In the light of the above literature review on the SHGs and its impact on rural women empowerment, the present study has its important to assess the impact of Women Self Help Groups on its members in terms of socio-economic empowerment. The findings of the study may be useful for policy imperatives and smooth functioning of SHGs.

\section{Objectives of the Study}

The major objectives of the present study are as follows:

- To examine the impact of SHGs on the social empowerment of rural women.

- To analyse the impact of SHGs on the economic empowerment of rural women.

- To assess the impact of SHGs on the educational empowerment of rural women.

- To explore the impact of SHGs on health empowerment of rural women.

- To explain the impact of SHGS on the political empowerment of rural women.

- To suggest the suitable measurers for the strengthening of SHGs and for the socioeconomic empowerment and development of rural women.

\section{Methodology of the Study}

For the purpose of the present study, Tanakallu Mandal of Kadiri revenue division in Ananthapuramu district of Rayalaseema region in Andhra Pradesh has been selected. From the selected Mandal, six revenue villages have been selected. From each revenue village, 20 sample SHG women have been selected on simple random sampling basis. This altogether covers, one revenue Mandal, six revenue villages and $120 \mathrm{SHG}$ women members from various categories.

\section{RESULTS AND DISCUSSIONS}

To analyse the impact of Self-Help Groups on the empowerment of rural women before and after establishment of Self-Help Groups method has been adopted. The different kinds of empowerment among 
the sample SHG rural women have been examined as follows.

- Social Empowerment

- Economic Empowerment

- Educational Empowerment

- Health Empowerment, and

- Political Empowerment

\section{Social Empowerment of Rural Women through SHGs}

The social empowerment means equal status, participation and power of decision making at the household level and at the community level as well as in all spheres of life. The social empowerment of women enables them to participate in decision making process in democratic institutions and at individual level. The social empowerment refers to enhanced status in the family and community, participation in decision making, access to government offices, freedom to travel anywhere on need based, group identity and increased awareness on society. According to Goel [24], the social empowerment of women refers to create an enabling environment through various affirmative development policies and programs for the development of rural women.

Table-1: Changing Indicators on Social Empowerment of Rural Women through SHGs

\begin{tabular}{|l|l|l|l|l|}
\hline \multirow{2}{*}{ Changing Indicators } & \multicolumn{3}{l|}{ Before SHG } & \multicolumn{2}{l|}{ After SHG } \\
\cline { 2 - 5 } & Yes & No & Yes & No \\
\hline Sharing Feelings Confidently with Others & $37(30.83)$ & $83(69.17)$ & $76(63.33)$ & $44(36.67)$ \\
\hline Gained Confidence and Self Esteem & $46(38.33)$ & $74(61.67)$ & $86(71.67)$ & $34(28.33)$ \\
\hline Fight Against Injustice and Inequality & $32(26.67)$ & $88(73.33)$ & $78(65.00)$ & $42(35.00)$ \\
\hline Respectful Treatment from Family Members & $45(37.50)$ & $75(62.50)$ & $82(68.33)$ & $38(31.67)$ \\
\hline Respectful Treatment from Society & $34(28.33)$ & $86(71.67)$ & $91(75.83)$ & $29(24.17)$ \\
\hline Receiving by Officials in the Govt. Offices & $28(23.33)$ & $92(76.67)$ & $89(74.17)$ & $31(25.83)$ \\
\hline Visiting Outside the Village Independently & $36(30.00)$ & $84(70.00)$ & $93(77.50)$ & $37(30.83)$ \\
\hline Attending for Markets Independently & $31(25.83)$ & $89(74.17)$ & $91(75.83)$ & $29(24.17)$ \\
\hline Domestic Violence & $67(55.83)$ & $53(44.17)$ & $40(33.33)$ & $80(66.67)$ \\
\hline Increased Mobility & $41(34.17)$ & $79(65.83)$ & $85(70.83)$ & $35(29.17)$ \\
\hline
\end{tabular}

Source: Field Survey Data, Figures in Parentheses Indicates Percentages to their Total

In the process of creating empowerment among the rural women in India, the Self-Help Groups concept has been established in the country. Through the involvement of rural women in SHGs, they earning money and this supports for social empowerment among the rural women. The following Table-1 presents the changing indicators of rural women on the social empowerment before and after their involvement in the activities of SHGs in the study area. It reveals that out of 120 sample SHG women, only 30.83 percent opined that before joining in SHGs, they shared their feelings confidently with others as against 61.67 percent opined that there is no improvement in sharing their feelings confidently with others. On the other side, 63.33 percent of the respondent SHG women opined that after joining in SHGs, there is an improvement in sharing their feelings with others and 36.67 percent expressed that there is no improvement in sharing their feelings as a women in the society.

It may also noticed that, 61.67 percent expressed their feelings that before joining in SHGs, they can't gained confidence and self-esteem and 38.33 percent said that before SHG also they gained confidence and esteem. After joining in SHG activities, 71.67 percent of sample respondent women have gained confidence and self-esteem and 28.33 percent have not yet gained confidence and self-esteem. It shows that before joining in SHGs, only 26.67 percent were fight against injustice and inequality and the remaining 73.33 percent were unable to fight against injustice and inequality. On the other, after joining in SHG activities, 65 percent of sample SHG women have been fighting against injustice and inequality against the women in the society.

It amy also observed that, only 37.50 percent of sample women opined that before joining in SHGs, they received respectful treatment from family members and the remaining 62.50 percent expreseed that due to poor income from them, they were not received respectful treatment from their family members. However, after joining in SHGs, 68.33 percent of SHG women opined that they received respectful treatment from their family members and only 31.67 percent expressed that they have not been received respectful treatment from family members. Before joining in SHGs, only 28.33 percent of sample women were received respectful treatment from society and 71.67 percent were neglected by the society in giving respectful treatment to the rural women. On the other, after joining in SHGs, 75.83 percent of SHG women opined that they received respectful treatment from the society and only 24 percent expressed that they have not received respecful treatment from society. 


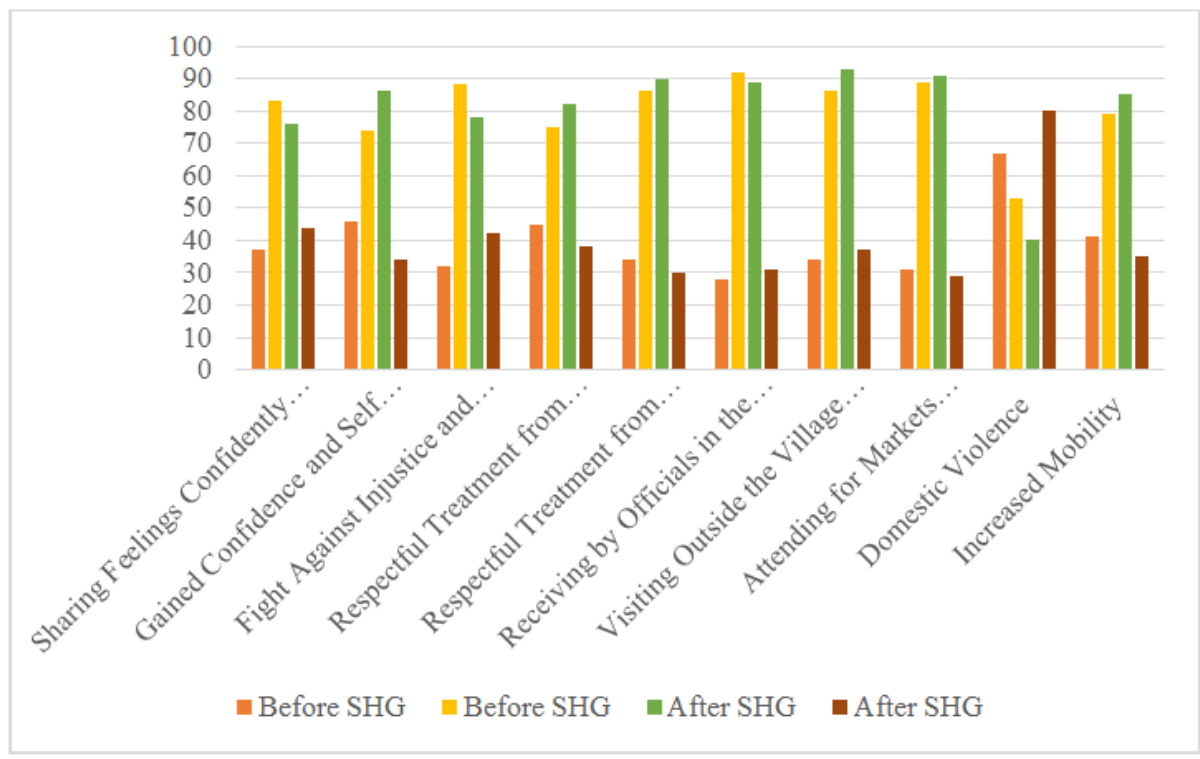

Diagram-1: Changing Indicators on Social Empowerment of Rural Women through SHGs

It shows that out of 120 respondent SHG women, about 23 percent of them opined that before joining in SHGs, receiving by government officials is satisfactory and the remaining 77 percent opined they have not received respectfully from government officials whenever they approached them. As against this, after joining in SHGs, 74.17 percent of women SHG members opined that they received respectful treatment by government officials as and when they approached for their works in the offices. It may also noticed that before joining in SHGs, only 30 percent of sample rural women were visted outside the village for their personal works and 70 percent of sample SHG women informed that they have not been visited outside the village independently. After joining in SHG activities, 77.50 percent of SHG women visted outside the village independently and the remaining 22.50 percent expressed that they are accompanied by their husbands during the visit of outside the village.

It reveals that before joining in SHGs, only 25.83 percent of rural women were attended the markets independently and 74.17 percent of women accompanied by their husbands to attend the markets. As against this situation, after joining in SHGs, a majority of 75.83 percent of SHG woemen expressed that they are attending to the markets independently to purchase the foodgrains and other domestic appliances. It reveals that before joining SHG activities, 55.83 percent of rural women were faced the domestic violence in the family and 44.17 percent expressed their feelings that they have not been faced any domestic violence. After joining in SHG programs, only 33.33 percent of rural women are suffering with domestic violence and the remaining 66.67 percent informed that they have not been facing any domestic violence after joining inn SHGs. Out of 120 sample women households under study, 65.83 percent of women informed that there is no improvement in the increased mobility among the SHG women, and after joining in SHGs, 7083 percent of sample SHG rural women expressed that there is an improvement in the increased mobilty among them. The changing indicators on the social empowerrment of women is diagrammatically presented in diagram 1 .

\section{Economic Empowerment of Rural Women through SHGs}

To achieve the gender equality and sustainable development, there is a need for economic empowerment of women as they are key contributors to the economies as producers of food, managers of natural resources and as entrepreneurs and employees. Inclusive and sustainable development around the world, leaving no one behind, is the overarching vision of the United Nation's 2030 Agenda. Gender equality and women's economic empowerment are central to realization of this vision, yet gender gaps around the world remain in large, pervasive and persistent. Women's economic empowerment is the right and smart thing to do. Women's rights are human rights case for gender equality is incontrovertible. The human development, economic and business gains from empowering women are substantial. Through the SHG activities, the rural women are earning additional income and are becoming economically empower in the society and in the family. The Table- 2 presents the data on the changing indicators of economic empowerment of sample SHG women, before and after they joining in SHGs. 
S. Chittemma \& K Dasaratharamaiah., Sch J Econ Bus Manag, May., 2020; 7(5): 183-196

Table-2: Changing Indicators on Economic Empowerment of Rural Women through SHGs

\begin{tabular}{|l|l|l|l|l|}
\hline Indicators & \multicolumn{3}{l|}{ Before SHG } & \multicolumn{2}{l|}{ After SHG } \\
\cline { 2 - 5 } & $\begin{array}{l}\text { Self- } \\
\text { Decision }\end{array}$ & $\begin{array}{l}\text { Decision Taken Jointly } \\
\text { by Husband and Wife }\end{array}$ & $\begin{array}{l}\text { Self- } \\
\text { Decision }\end{array}$ & $\begin{array}{l}\text { Decision Taken Jointly } \\
\text { by Husband and Wife }\end{array}$ \\
\hline $\begin{array}{l}\text { Decision Making Power in Utilising household } \\
\text { Income }\end{array}$ & $26(21.67)$ & $94(78.33)$ & $71(59.17)$ & $49(40.83)$ \\
\hline Decision Making Power in Taking Loans & $13(10.83)$ & $107(89.17)$ & $68(56.67)$ & $52(43.33)$ \\
\hline $\begin{array}{l}\text { Freedom to Use the Money for Personal Needs } \\
\text { of SHG Women }\end{array}$ & $17(14.17)$ & $103(85.83)$ & $81(67.50)$ & $3932.50)$ \\
\hline $\begin{array}{l}\text { Maintaining Savings in the Name of SHG } \\
\text { Women }\end{array}$ & $11(9.17)$ & $109(90.83)$ & $87(72.50)$ & $33(27.50)$ \\
\hline $\begin{array}{l}\text { Agricultural Lands in the Name of SHG } \\
\text { Women }\end{array}$ & $39(32.50)$ & $79(65.83)$ & $65(54.17)$ & $55(45.83)$ \\
\hline $\begin{array}{l}\text { Utilising Savings Amount for the Need of SHG } \\
\text { Women }\end{array}$ & $10(8.33)$ & $110(91.67)$ & $96(80.00)$ & $24(20.00)$ \\
\hline $\begin{array}{l}\text { Decision Making Power in Purchase of Home } \\
\text { Appliances }\end{array}$ & $54(45.00)$ & $66(55.00)$ & $98(81.67)$ & $22(18.33)$ \\
\hline Decision Making Power in Purchase of Cloths & $67(55.83)$ & $53(44.17)$ & $84(70.00)$ & $36(30.00)$ \\
\hline $\begin{array}{l}\text { Decision Making Power in Purchase of } \\
\text { Cosmetics }\end{array}$ & $72(60.00)$ & $48(40.00)$ & $101(84.17)$ & $19(15.83)$ \\
\hline $\begin{array}{l}\text { Changes in Borrowing Capacity of SHG } \\
\text { Women }\end{array}$ & $07(5.83)$ & $113(94.17)$ & $91(75.83)$ & $29(24.17)$ \\
\hline
\end{tabular}

Source: Field Survey Data, Figures in Parentheses Indicates Percentages to their Total

It reveals that before SHG activities in the study area, out of 120 sample SHG women respondents, 21.67 percent have taken a self-decision in utilizing the household income to meet the family needs and against this, 78.33 percent of sample SHG rural women have not taken an independent decision, but taken a decision on spending household income jointly with their husbands. It shows that here the husbands' role is more in taking a decision in utilizing the household income for their family needs. On the other side, after joining in SHGs, the same rural women have empowered to take a decision in utilizing income. It reveals that 59.17 percent of SHG rural women have taken independent decision in utilizing the household income as against 40.81 percent of the SHG women have taken a decision jointly with their husbands.

It may also observed that before joining in SHGs, the decision making power of rural women in taking loans is poor with 10.83 percent of rural women, but 56.67 percent of rural women have taken an independent decision in taking loans for various purposes of their family. Before joining in SHGs, 89.17 percent of respondent SHG women have jointly with their husbands have taken a decision in taking loans and after joining in SHGs only 43.33 percent are jointly taken decisions in taking loans. It shows that after joining in SHGs the rural women have an empowerment in taking decision on receiving loans from various sources. It shows that before joining in SHGs, only 14.17 percent of sample women have a freedom to use money for their personal needs and 85.83 percent have taken a decision with their partners in utilizing money for the personal needs of the women. Out of 120 sample women, after joining in SHGs, 67.50 percent of women have a freedom in spending money for their personal needs as they are earning money from SHG activities. Only 32.50 percent of sample SHG women have taken a joint decision along with life partners on spending money for personal needs.

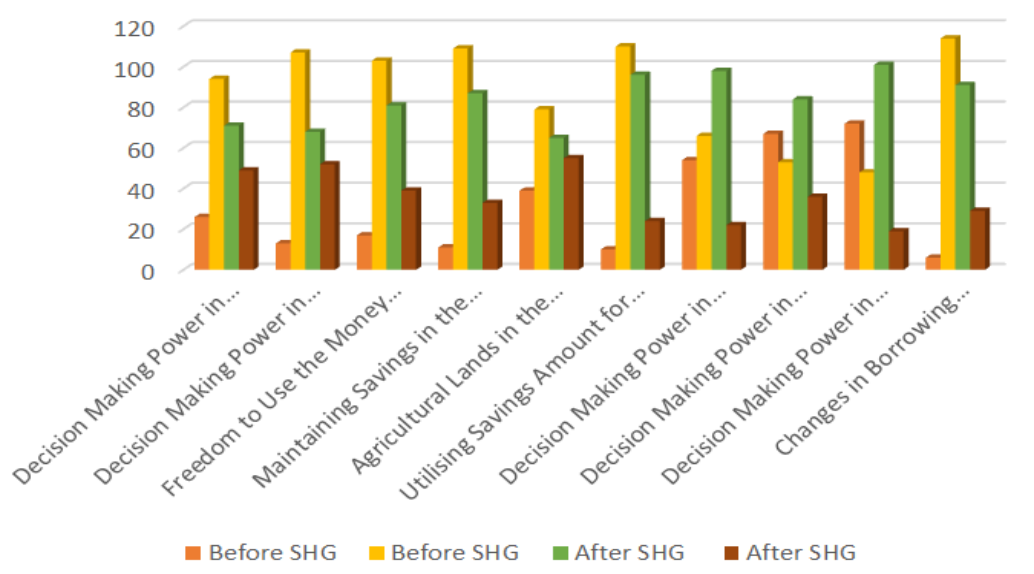

Diagram-2: Changing Indicators on Economic Empowerment of Rural Women through SHGs 
It may also noticed that before joining in SHGs, only 9.17 percent of sample SHG women have taken decisions independently on savings as against 90.83 percent have taken decisions along with their husbands or the head of the family only. After joining in SHGs, a majority of 72.50 percent of SHG women have taken self-decision in managing savings from their income and only 27.50 percent of SHG women still depends on their husbands for saving of money from their earnings. It reveals that before joining in SHG activities, only 32.50 percent of rural women have agricultural lands in their name and after joining in SHGs, 54.17 percent of women have an ownership of land in their names. Out of 120 sample women under study, before joining in SHGs, only 8.33 percent of rural women have a liberty in spending the savings amount for their personal needs as against 91.67 percent of them depends on family members to spend the saved money for their personal needs. After joining in SHGs, 80 percent of sample women have an empowerment of taking independent decision in utilizing the savings for their personal needs and only 20 percent are depending on husbands to take a decision to spend the savings amount for personal needs.

As shown in Table-2, before joining in SHGs, 45 percent of sample women have a decision making power in purchase of home appliances and the remaining 55 percent depends on their husbands to take a decision to purchase home appliances. On the other side, after joining in SHG activities, 81.67 percent of sample SHG women have taken self-decision in purchase of home appliances and only 18.33 percent are depending on family members to take a decision to purchase home appliances. Out of 120 sample SHG respondents under study, before joining in SHG activities, 55.83 percent of women have a decision making power in purchase of cloths and against this, 44.17 percent depends on family members to take a decision to purchase cloths. After joining in SHGs, 70 percent of sample SHG women have taken self-decision in purchase of cloths and the remaining 30 percent of sample SHG women have jointly taken a decision to purchase cloths for them and their family members.

It may also noticed that, before joining in SHGs, 60 percent of women have self-decision making power in purchase of cosmetics and 40 percent have taken a decision jointly with their husbands. After joining in SHGs, 84.17 percent of sample women have taken self-decision in purchase of cosmetics and only 15.83 percent have taken a decision jointly with their partners in purchase of cosmetics. Out of 120 Sample SHG women under study, only 5.83 percent of SHG women opined that before joining in SHGs, they have no borrowing capacity and 94.17 percent informed that their family members have taken a self-decision to borrow the money. After joining in SHGs, 75.83 percent of SHG women have self-decision in borrowing money and only 24.17 percent of SHG women have jointly taken a decision to borrow the money for family needs. The diagram 2 is diagrammatically illustrates the decision making power on economic activities by SHG women before and after joining in SHGs under study.

\section{Health Empowerment of Rural Women through SHGs}

The health empowerment can be defined as a process in which patients understand their role, knowledge and skills by their health care provider to perform a task in a healthy environment. The health empowerment puts the person in the heart of services. It is about designing and delivering health and social care services in a way, which is inclusive and enables the individual to control their health care needs. Women with greater agency are more likely to have fever children, more likely to access health services and have control over health resources. The SHGs creating awareness among its women members on health care. Due to health awareness form the SHGs, the rural women are taking care their health and consulting doctors frequently. The changing indicators on health empowerment of rural women before and after joining in SHGs is presented in Table-3.

Table-3: Changing Indicators on Health Empowerment of Rural Women through SHGs

\begin{tabular}{|l|l|l|l|l|}
\hline \multirow{2}{*}{ Indicators } & \multicolumn{2}{l|}{ Before SHG } & \multicolumn{2}{l|}{ After SHG } \\
\cline { 2 - 5 } & Yes & No & Yes & No \\
\hline Frequent Consultation with Doctors & $48(40.00)$ & $72(60.00)$ & $77(64.17)$ & $43(35.83)$ \\
\hline Decision Taken to Adopt Family Planning & $58(48.33)$ & $62(51.67)$ & $83(69.17)$ & $37(30.83)$ \\
\hline Vaccination & $89(74.17)$ & $31(25.83)$ & $104(86.67)$ & $16(13.33)$ \\
\hline Access to Health Services & $51(42.50)$ & $69(57.50)$ & $91(75.83)$ & $39(32.50)$ \\
\hline Sanitary Facilities & $37(30.83)$ & $83(69.17)$ & $95(79.17)$ & $25(20.83)$ \\
\hline Taking Nutritious Food & $34(28.33)$ & $86(71.67)$ & $87(72.50)$ & $33(27.50)$ \\
\hline
\end{tabular}

Source: Field Survey Data, Figures in Parentheses Indicates Percentages to their Total

It is observed that, before joining in SHG, only 40 percent of respondent SHG women were frequently consulted the doctors for medical treatment and the remaining 60 percent of sample women living in rural areas were occassionally consulted the doctors for treatment. After joining in SHG activities, 64.17 percent of sample SHG women are frequently visiting the hospitals for their medical treatment. It may also noticed that before joining in SHG, out of 120 respondent women, 48.33 percent were taken an independent decision to adopt family planning methods and 51.67 percent were followed the instructions of 
family members to adopt the family planning methods. As against this, after joining in SHG programmes in the study area, 69.17 percent of the sample $\mathrm{SHg}$ women were taken self decision to adopt family planning.

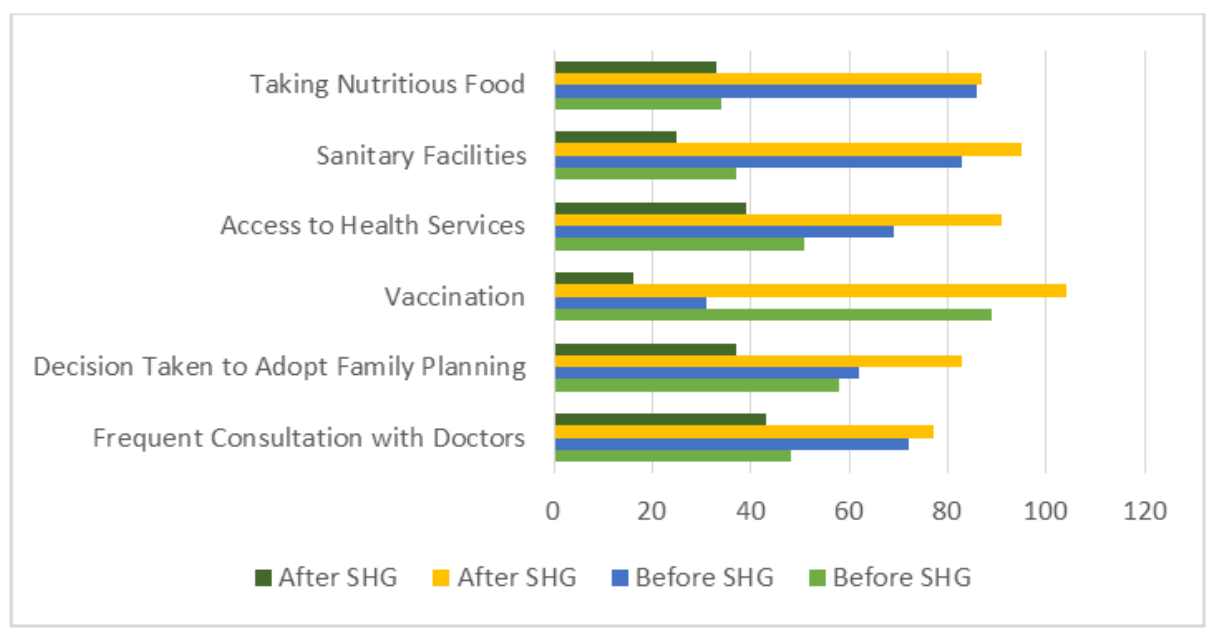

Diagram-3: Changing Indicators on Health Empowerment of Rural Women through SHGs

It may also observed that, before SHG, 74.17 percent of sample women have taken vaccination independently and the remaining 25.83 percent have undertaken vaccination with the help of others. On the otherside, after joining in SHG activities, 86.67 percent of sample women have taken self- decision to take the vaccination and the remaining through the suggestion of family members or not taken the vaccination for some one. Access to health services are necessary to maintain good health condition. It is observed that before joining in SHG, 42.50 percent of rural women have accessibility to health services and 57.50 percent have no accessibility to health services. After joining in SHGs, 75.82 percent of SHG women respondents have accessibility to health services and the remaining 32.50 percent have no accessibility to health services.

It reveals that before joining in SHG activities, only 30.83 percent of the rural women have cleaning and sanitary facilities at their homes and 69.17 percent of the respondent women have not been properly followed the cleaning and sanitary arrangements at their houses. After joining in SHGs, 79.17 percent of SHG women are maintaining proper cleaning and sanitary facilities and a few of them (20.83 percent) have no proper cleaning and sanitary facilities. Before joining in SHG, 71.67 percent of rural women have not been taken nutritious food to maintain good health and only 28.33 percent have taken nutritious food. After joining in SHG, the SHG officials were educated the rural women on the importance and necessity of the nutritious food. Based on the creation of awareness by SHGs, now 72.50 percent of the sample rural women are taking nutritious food. The changing indicators on health empowerment of rural women before and after the SHG, is diagrammatically shown in diagram 3.

\section{Educational Empowerment of Rural Women through SHGs}

Education is a milestone for women empowerment as it enables the women to respond to the challenges, to confront their traditional role and change in their life style. The education helps a woman to understand her rights to equal treatment on par with man in the society. Women can be empowered only when they are literate and educated. The education is the key to unlock the golden door of freedom for development. Of Indian women today, the female literacy levels according to 2011 literacy rate has been 65.46 percent as against male literacy rate of about 80 percent. Education is the key factor for women empowerment, prosperity, development and welfare. Discrimination of women from womb to tomb is well known factor. The SHGs are educating its members on the importance of education for rural women in all spheres of life, because of this, the rural women are concentrating on their education and their children's education and ultimately they are getting educational empowerment. The Table-4 presents the changing indicators of SHG women on their educational empowerment before and after joining in SHGs.

It reveals that before joining in SHGs, the awareness on learning, reasoning and questioning is poor among the sample women and shows that a majority of 79.17 percent of sample SHG women have no knowledge on learning, reasoning and questioning. It may also noticed that after joining in SHGs, 55.83 percent of sample women have knowledge and awareness on learning, reasoning and questioning the issues and the remaining 44.17 percent of the sample respondents are not yet concentrating in learning, reasoning and questioning due to their rural and traditional backgrounds. 
Table-4: Changing Indicators on Educational Empowerment of Rural Women through SHGs

\begin{tabular}{|l|l|l|l|l|}
\hline \multirow{2}{*}{ Indicators } & \multicolumn{2}{l|}{ Before SHG } & \multicolumn{2}{l|}{ After SHG } \\
\cline { 2 - 5 } & Yes & No & Yes & No \\
\hline Learning Reasoning and Questioning & $25(20.83)$ & $95(79.17)$ & $67(55.83)$ & $53(44.17)$ \\
\hline Decision Taken in Joining Children in the Schools & $43(35.83)$ & $77(64.17)$ & $99(82.50)$ & $21(17.50)$ \\
\hline Concentration on Children's Education at Home & $30(25.00)$ & $90(75.00)$ & $93(77.50)$ & $27(22.50)$ \\
\hline Visiting Schools of Children & $22(18.33)$ & $98(81.67)$ & $87(72.50)$ & $33(27.50)$ \\
\hline Awareness on Sending Children to Higher Studies & $29(24.17)$ & $91(75.83)$ & $95(79.17)$ & $25(20.83)$ \\
\hline Communication with others & $35(29.17)$ & $85(70.83)$ & $90(75.00)$ & $30(25.00)$ \\
\hline Usage of Technical Appliances & $19(15.83)$ & $101(84.17)$ & $75(62.50)$ & $45(37.50))$ \\
\hline Learning Technical Skills & $18(15.00)$ & $102(85.00)$ & $69(57.50)$ & $51(42.50)$ \\
\hline Habit of Reading News Papers & $26(21.67)$ & $94(78.33)$ & $79(65.83)$ & $41(34.17)$ \\
\hline Habit of Watching TVs & $84(70.00)$ & $36(30.00)$ & $110(91.67)$ & $10(8.33)$ \\
\hline
\end{tabular}

Source: Field Survey Data, Figures in Parentheses Indicates Percentages to their Total

It may also noticed that before joining in SHGs, only 35.83 percent of sample women are able to take a decision on joining their children in the schools and the remaining 64.17 percent of SHG women are depending on their family members to take a decision to join their children in the schools. After joining in SHGs, 82.50 percent of rural women are able to take a decision to join their children in the schools and a little of 17.50 percent are depending on their family members to take a decision to join the children in the schools. It shows that before joining in SHGs, 75 percent of the sample rural women have no concentration on children's education at home and only 25 percent have concentrated on their children's education at home. After joining in SHGs, a majority of 77.50 percent of mothers are able to concentrate on children's education at home. It may also observed that before SHGs, only 18.33 percent of rural mothers have been visited the schools, where their children are studying and a majority of 81.67 percent of rural women are unable to visit the schools due to their illiteracy and ignorance. It may also noticed that after joining in SHGs, 72.50 percent of rural women are visiting the schools to observe the performance of their children in the schools.

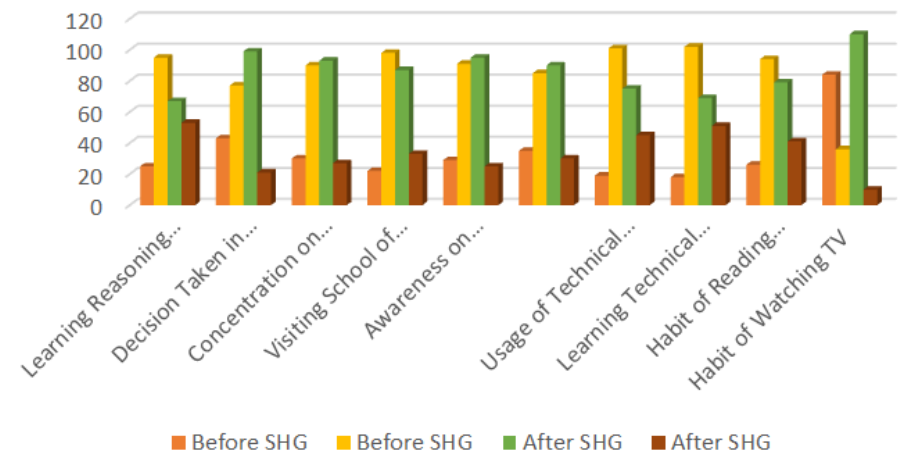

Diagram-4: Changing Indicators on Educational Empowerment of Rural Women through SHGs

It may also observed that before SHGs, there is a poor awareness on sending their children for higher studies. It shows that 75.83 percent of rural women have no awareness on sending their children for higher studies and after the joining in SHGs, they have been improved their awareness on sending their children for higher studies. As shown in Table-4, a majority of 79.17 percent of rural women have an awareness on higher studies and are sending their children for further higher studies. It reveals that before joining in SHGs, only 29.17 percent of rural women have communication with others and a majority of 70.83 percent have no communication with others. After joining in SHGs, a majority of 75 percent of rural women have improved their communication with others in the society through acquiring knowledge and communication skills.
It shows that before joining in SHGs, only 15.83 percent of sample women are able to usage of technical appliances and 84.17 percent are unable to use technical appliances in the house. As against this, after joining in SHGs, 62.50 percent of respondent SHG women have acquired knowledge on the usage of technical appliances and the remaining 37.50 percent have not acquired the knowledge on usage of technical appliances. It may also noticed that before joining in SHGs, only 85 percent of women have not been learned any technical skills. After joining in SHGs, a majority of 57.50 percent of sample women have acquired knowledge on technical skills. 
As shown in Table-4, before joining in SHGs, only 21.67 percent have a habit of reading newspapers and 78.33 percent have no habit of reading newspapers. On the other, after joining in SHGs, 65.83 percent of respondent women have improved their interest in reading newspapers. It may also noticed that before joining in SHGs, 70 percent of respondent women have a habit of watching TVs and 30 percent have no habit of watching TVs. After joining in SHGs, 91.67 percent of SHG women have concentrated on watching TVs and only 8.33 percent have not been watching TVs. The changing indicators on educational empowerment of rural women through SHGs is diagrammatically illustrated in diagram 4 under study.

\section{Political Empowerment of Rural Women through SHGs}

The political empowerment refers to the process of transferring various elements of power i.e. resources, capabilities and positions to those who do not have it. Political empowerment requires inclusion in democtratic decision making process. The political empowerment of women is a social process, crucial to development and progress of the individual as well as the nation. The status of women is measured internationall by the participation of women in politics and thir empowerment in politics. In recent years, women participation in politics has been gradually increasing but not drastically. To secure women's rightful place in society and to enable them to decide their own destiny and for the growth of genuine and sustainable democracy, women's participation in politics is essential. Their particiaption in public life will solve many problems in the society. The SHGs in the rural areas are encouraging and educating the rural women to particiapate in public life and are joinig in the political activities. The Table-5 illustrates the changing indicators of political empowerment of women before and after joining in SHGs.

It may be noticed that before SHG program, only 11.67 percent of SHG women have awareness on women Rights and Acts and 88.33 percent of rural women have no awareness on women Rights and Acts. After joining in SHGs, 70 percent of respondent SHG women have a knowledge and awareness on women Rights and Acts. It may also observed that before joning in SHGs, only 15.83 percent of the sample respondents opined that they have an awareness on reservation of seats for women in local bodies, but a majority of 84.17 percent of SHG women have no awareness on reservation of seats for women in local bodies. After joining in SHGs, 58.33 percent of SHG women got an awareness on reservation of seats for women in local bodies.

Table-5: Changing Indicators on Political Empowerment of Rural Women through SHGs

\begin{tabular}{|l|l|l|l|l|}
\hline Indicators & Before SHG & \multicolumn{1}{l|}{ After SHG } \\
\cline { 2 - 5 } & Yes & No & Yes & No \\
\hline Awareness on Women Rights and Acts & $14(11.67)$ & $106(88.33)$ & $84(70.00)$ & $36(30.00)$ \\
\hline Awareness on Reservation of Seats for Women in Local Bodies & $19(15.83)$ & $101(84.17)$ & $70(58.33)$ & $50(41.67)$ \\
\hline Awareness on Reservation of Gram Panchayats for Women & $23(19.17)$ & $97(80.83)$ & $87(72.50)$ & $33(27.50)$ \\
\hline Participation in Gram Sabhas & $10(8.33)$ & $110(91.67)$ & $103(85.33)$ & $17(14.17)$ \\
\hline Participation in Political Party Meetings & $12(10.00)$ & $108(90.00)$ & $94(78.33)$ & $26(21.67)$ \\
\hline Participation in Other Social Activities & $09(7.50)$ & $111(92.50)$ & $83(69.17)$ & $37(30.83)$ \\
\hline $\begin{array}{l}\text { Freedom in taking Decision to Vote in favour of any Candidate in } \\
\text { Elections }\end{array}$ & $46(38.33)$ & $74(61.67)$ & $99(82.50)$ & $21(17.50)$ \\
\hline
\end{tabular}

Source: Field Survey Data, Figures in Parentheses Indicates Percentages to their Total

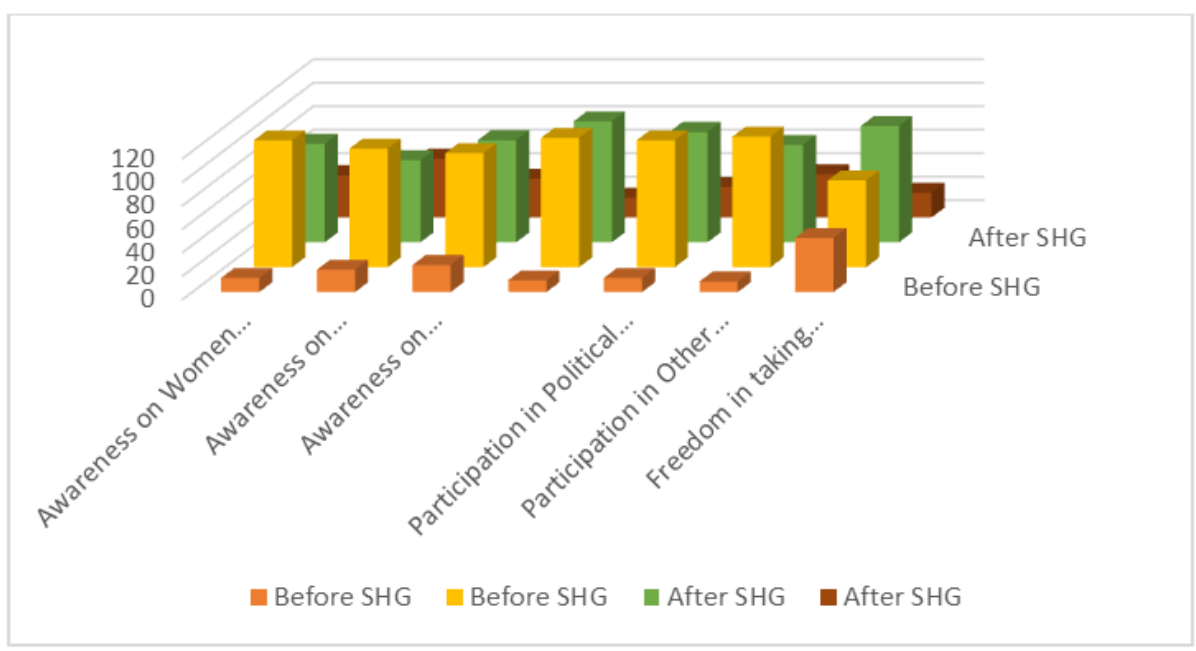

Diagram-5: Changing Indicators on Political Empowerment of Rural Women through SHGs 
It may also observed that before joining in SHGs, 19.17 percent of sample SHG women expressed their view that they have an awareness on resrvation of gram panchayats for women and 80.83 percent opined that they have no awareness on reservation of gram panchayats for women. On the other side, after joining in SHGs, a majority of 72.50 percent have awareness on reservation of gram panchayats for women. Out of 120 sample SHG women under study, only 8.33 percent of respondent women were participated in Gram Sabha meetings before joining in SHGs and a majority of 91.67 percent were not participated in Gram Sabhas. After joining in SHGs, a majority of 85.33 percent of respondent women were paticipated in Gram Sabha meetings.

It reveals that before SHGs, only 10 percent of rural women were participated in political party meetings and the remaining 90 percent were not participated in political party meetings. After joining in SHGs, a majority of 78.33 percent were participated in political party meetings. It shows that before SHGs, only 7.50 percent of sample SHG women were particiapted in other social activities as against 92.50 percent were not attended any social functions/activities. After joining in SHGs, 69.17 percent of respondent SHG women are participating in other social activies.

Before SHG activities, only 38.33 percent of sample women opined that they have freedom in taking decisions to vote in favour of any candidate in the elections as per their wish and a majority of 61.67 percent informed that they have no freedom in taking a decision to vote in favour of any candidate in elections as their wish. It is observed that after joining in SHGs, a majority of 82.50 percent of SHG women opined that they have freedom in taking a decision to vote in favour of any candidate in elections as per their wish. The changing indicators on political empowerment of SHG women before and after joining in SHGs is diagrammatically shown in diagram 5 .

\section{CONCLUSIONS}

The women empowerment is gaining importance with an added significance in the context of India. The women empowerment has become a subject of growing importance around the world in contemporary times. Women in Indian society have come a long way from the days of being worshipped as goddess. According to Keshab Chandra Mandal, there are five categories of women empowerment such as social, economic, educational, political and psychological. The empowerment by way of involvement in SHGs can bring changes and enhanced the living conditions of rural women. As a group oriented model, SHGs in India is a mechanism for women development to bring individual and collective empowerment.
The empirical data reveals that a majority of rural women involved in SHGs have improved their decision taking power in spending money, taking loans, uttilising money for personal needs. The head of the family is giving preference to the SHG women member of their family in taking financial decisions in the family after she joined in SHGs. It may also observed that majority of sample SHG women have gained social empowerment after joining in SHGs. They are sharing their feelings confidently with others, fighting against injustice and inequality, visiting outside the village and market places independently without accompany of their husband or other family members. The domestic violence has also been reduced in their families after joining in SHGs.

It reveals that the SHG women have also gained health empowerment after joining in SHG activities. Now, they are frequently visiting hospitals independently for medical treatment, taking decisions independently on adopting family planning, vaccination and access to health services. The educational empowerment has also improved among SHG women after SHG activities. They are taking decisions in sending their children to the school and visiting the schools to observe the performance of their children. Also taking decisions independently to send their children for higher studies. Reading of newspapers and watching TVs by SHG women have also been changed after joining in SHGs.

The rural women have also gained the political empowerment after joining in SHGs. It is observed that a majority of SHG women have awareness on women Rights and Acts, reservation of seats for women in local bodies, and reservation of gram panchayats for women. Now, they are participating actively in Gram Sabha meetings, political party meetings and other social activities. They are taking independent decisions in casting their vote as they wish.

\section{REFERENCES}

1. Mohanan PV, Rao JM, Kutti MA, Devi KS. Cytotoxicity of extracts of Solanum trilobatum and anticarcinogenic activity of sobatum. Biomedicine. 1998;18(2):106-1.

2. Puhazhendhi V, Jayaraman B. Rural credit delivery: Performance and challenges before banks. Economic and Political Weekly. 1999 Jan 16:175-82.

3. Datta AK, Gurumurthy S, Petit F, Villain V. Selfstabilizing network orientation algorithms in arbitrary rooted networks. InProceedings 20th IEEE International Conference on Distributed Computing Systems 2000 Apr 10 (pp. 576-583). IEEE.

4. Vijayanthi KN. Women's empowerment through self help groups-A participatory approach. Social Change. 2000 Sep;30(3-4):64-87. 
5. Bhatia M, Brady M, Shokuhi S, Christmas S, Neoptolemos JP, Slavin J. Inflammatory mediators in acute pancreatitis. The Journal of Pathology: A Journal of the Pathological Society of Great Britain and Ireland. 2000 Feb;190(2):117-25.

6. Mishra C, Prins HH, Van Wieren SE. Overstocking in the trans-Himalayan rangelands of India. Environmental Conservation. 2001 Sep;28(3):279-83.

7. Veluraj R. SHGs an alternative approach to empower rural women. Tamil Nadu Journal of Cooperation. 2001 Jun;1(8):18.

8. Seibel HD, Harish Kumar RD. Commercial Aspects of SHGs Banking in India: A Study of Bank Transaction Costs, Thompson Press, Mumbai, 2002.

9. Jothy K, Sundar I. Self-help groups under the women's development programme in Tamil Nadu: Achievements, bottlenecks and recommendations. Social Change. 2002 Sep;32(3-4):195-204.

10. Rao VM. Women Self Help Groups Profiles from Andhra Pradesh and Karnataka. National Bank News Review. 2002 Apr;18(2):62-8.

11. Bharat D. Women Self Help Groups, Kurukshetra, March 2002, 50(5):40-42.

12. Sivaramakrishnan K. Poverty Alleviation through Self Help Groups', Cooperation, March 2003, 3(5):8-14.

13. Leelavathy, SHG is a Creamy Layer for Women's Social Status, Proceedings of National Level Symposium on Self Help Groups: A Silent Revolution, Arulmigu Palaniandavar Arts College for Women, Palani, March 2004.

14. Kour A. Self-Help Group (SHG) and Rural Development, Kurukshetra, December 2008, 57(2):25-29.

15. Sivachithappa K. Success story of Poverty Alleviation Through Self-Help Groups. Kurukshetra, Journal on Rural Development, Ministry of Rural Development, New Delhi. 2008 Dec;57(2):35-8.
16. Krishnan L, Sequeira AH, Snehalatha M. Empowerment of underprivileged women through self-help groups. Journal of Community Guidance \& Research. 2008 Mar 4;25(1):62-74.

17. Munian A. Micro finance and poverty reduction: Analytical issues. Southern Economist. 2009 May 1;48(1):41-2.

18. Pandey J, Rini R. A Study on Empowerment of Rural Women through Self-Help Groups, Abhinav: National Montly Refereed Journal of Research in Commerce and Management, 2011:1(8).

19. Sahu L, Singh SK. A qualitative study on role of self help group in women empowerment in rural Pondicherry, India. National Journal of Community Medicine. 2012;3(3):473-9.

20. Vijayalakshmi D, Gowda KN, Jamuna KV, Ray BR, Sajjan JT. Empowerment of Self-Help Group Women through Value Addition of Finger Millet, Journal of Dairying, Foods and Home Sciences, 2012, 31(3):223-226.

21. Dhanalakshmi U, Rajini K. A Review of Literature: Women Empowerment through SelfHelp Groups (SHGs). International Journal of Research in Commerce and Management. 2013;4(10):29-35.

22. Ramakrishna H, Mohinuddeen JK, Saleema GB, Mallikarjuna B. Performance of Self Help GroupBank linkage programme (SBLP) in India-An analytical study. Tactful Management Research Journal. 2013 Jul;1(10):1-6.

23. Kappa K. Women Empowerment through Self Help Groups in Andhra Pradesh, India, International Research Journal of Social Sciences, January 2014, 3(1):13-17.

24. Goel MS, McCarthy EP, Phillips RS, Wee CC. Obesity among US immigrant subgroups by duration of residence. Jama. 2004 Dec $15 ; 292(23): 2860-7$. 